\title{
A Visual Glossary: Delirio Güero (White Delusion)
}

\author{
Nina Hoechtl
}

Besides collective denials of the past (such as brutalities against indigenous peoples), people may be encouraged to act as if they don't know about the present. Whole societies are based on forms of cruelty, discrimination, repression or exclusion which are "known" about but never openly acknowledged ... Indeed, distortions and self-delusions are most often synchronized ... Whole societies have unmentioned and unmentionable rules about what should not be openly talked about. You are subject to a rule about obeying these rules, but bound also by a meta-rule which dictates that you deny your knowledge of the original rule.

Stanley Cohen (2001: 10-11, 45).

In this chapter I propose a visual glossary of what I have conceived as delirio güero (white delusion). It derives from my essay film/video performance/fake history show/future re-enactment titled DELIRIO GÜERO WHITE DELUSION 1825, 2018, 2211 and back $(2019 / 2211)$.

The film takes a deep dive into the nitty-gritty of the outlandish acts of nineteenth-century self-appointed discoverer/artist Jean-Friedrich Waldeck, and architect/researcher/photographer 
Teobert Maler, and the colonial imperial undertakings of the monarchs Charlotte of Belgium and Maximilian of Habsburg in Mexico, along with his follower, the Früchterl [swindler] Anton "Toni" Mayr, a distant relative of the güera film-maker/artist. My intention is to articulate three keywords that enable a necessarily incomplete dialogue around delirio güero-a dialogue that does not reduce this concept to my audio-visual assemblage but engages it as a complex practice of entanglement and entitlement, implication and aspiration, innocence and ignorance, denial and delusion.

\section{Whitey \\ Mask/ing \\ Blanquitud}

I have ceaselessly driven ... to show the white man that he is at once the perpetrator and the victim of a delusion.

Frantz Fanon (1986: 225).

I will take off my ski mask when Mexican society takes off its own mask, the one it uses to cover up the real Mexico ... And once they have seen the real Mexico-as we have seen it-they will be more determined to change it.

Subcomandante Marcos (1995: 70).

While watching (or fast forwarding) the film, the latex face and/ or hand masks are always present: they announce the artifice of identity by emphasizing the host's blanquitud (whiteyness). ${ }^{1}$

1 Echeverría (2018: 26) differentia tes between blanquitud (whiteyness) and blancura (whiteness): "We can call blanquitud the visibility of an ethical 


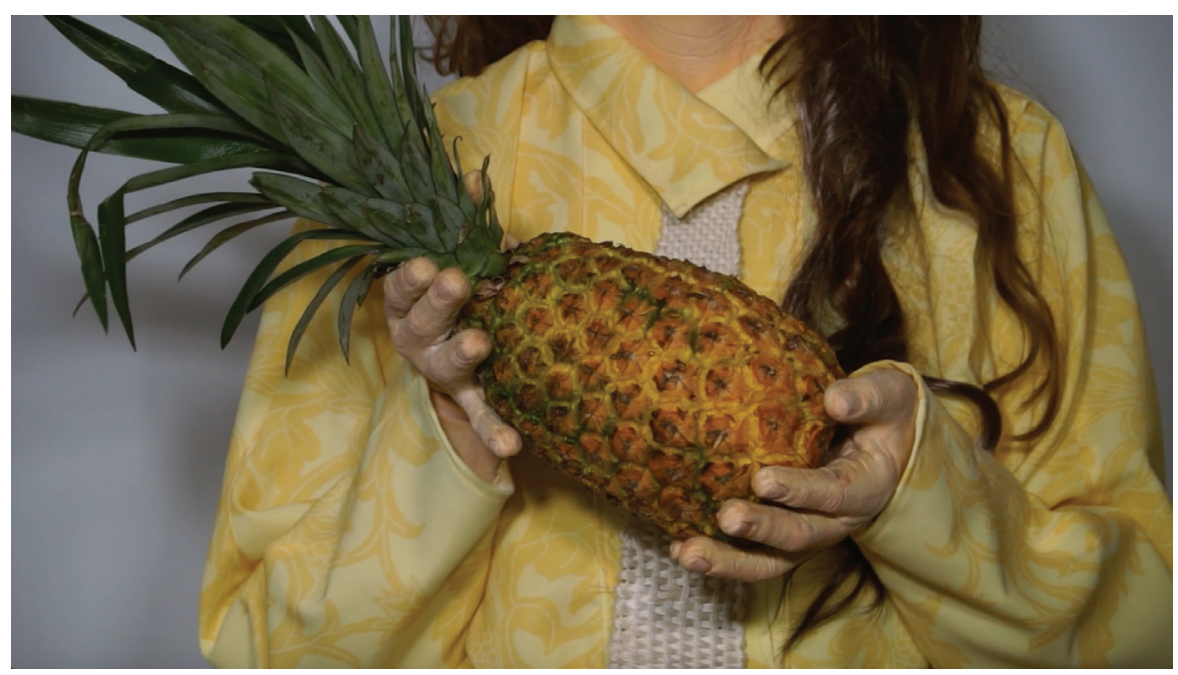

Figure 1.

Bolívar Echeverría $(2009,2010,2018)$ coined the term blanquitud and its translation, whiteyness, after Rainer Werner Fassbinder's movie Whity (1971), in reference to the figure of the illegitimate son of the white rancher born from the Black cook acting as the obedient butler Whity in the movie. Echeverría (2009, 2010, 2018) introduces blanquitud to grasp an identity that is brought into being by the homogenizing mandates of capitalism. While blanquitud includes certain ethnic white features and behaviours, it is not so much an ethnic category but an ethical and cultural one, directly linked to the homo capitalisticus, which threatens to spread throughout the world, overcoming, incorporating and co-opting identities that might otherwise resist it. Like Whity, it is through blanquitud that people of colour could obtain the whitey identity, an abstract-universal identity needed to be part of and serve the capitalist modern system as homo capitalisticus

capitalist identity insofar as it is overdetermined by the racial blancura, but by a racial blancura that relativizes itself through exercising its overdetermination" (translation by the author). 
without having to "whiten" completely (Echeverría 2018: 26). In Fassbinder's film, as soon as Whity pulls out money and performs masculinity by drinking half a bottle of whiskey, he is accepted by the white cowboys who had earlier denied him access to the saloon. Whity's acceptance is achieved through his individual acts but the cowboys' racist views are not shattered, nor is the racist structure in place challenged. ${ }^{2}$ Modern racism-the racism defined in relation to blanquitud-as Echeverría (2009) explains, "remains generally in the stage of scorn or contempt, of distrust and suspicious fear. Apparently harmless, this radical discrimination condemn[s] as no[n]-human (as un-menschen) everyone who has not found the way to success. And 'non-human' means dispensable, ready to be eliminated if the circumstances require." Given such a threat, let's all employ a whitey mask to become homo capitalisticus, and, if you don't, it's your own doing! (Nothing more distressing than that.)

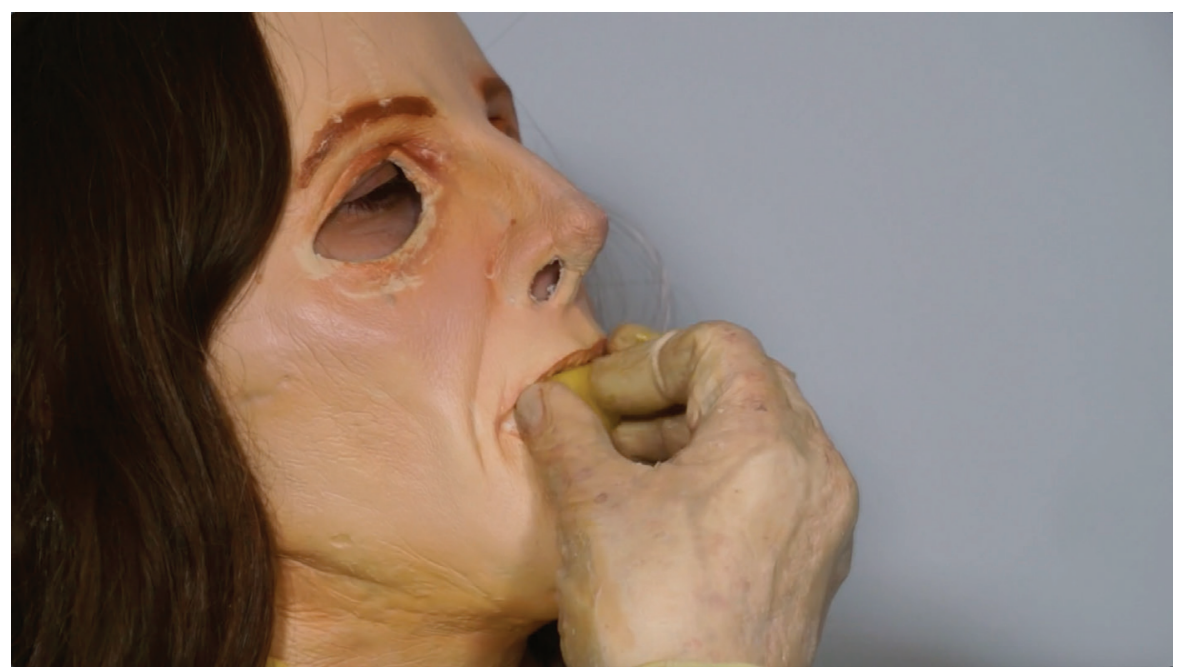

Figure 2.

2 For a close reading of Whity, see Prisciall D. Layne, "Lessons in Liberation: Fassbinder's Whity at the Crossroads of Hollywood Melodrama and Blaxploitation". Companion to German Cinema. Terri Ginsberg and Andrea Mensch (eds). Malden, MA: Wiley Blackwell Press, 2012, 260-286. 
The American Psychiatric Association's Diagnostic and Statistical Manual of Mental Disorders (DSM-5) considers a delusion to be "fixed beliefs that are not a menable to change in light of conflicting evidence" (APA 2013: 87). The delirio güero is characterized by the tendency not to see nor understand-even to deny-racism even though-or, more accurately, precisely because-the whitey identity fully benefits from its ongoing racial, economic and socio-ecological inequalities. Consequently, the delirio güero plays a crucial role in the construction and maintenance of white privilege, entitlement and violence including the knowledge and images that it has generated, in the case of the film, about cultures and peoples in Mexico. In the film, the deployment of the masks points to the intimate relationship-the latex material rubbing against the skin, making it sweat-between power, knowledge, entitlement, (audio-visual) image production, and processes of colonial imperialism. I am less interested here in a simple opposition between delirium and knowledge than I am in delirio güero as a wilful production of particular kinds of knowledge and (audio-)visual assemblages: Rather than being antithetical, delirium and knowledge are mutually constitutive and better understood and tackled as masking processes.

\title{
Mugs and Güero Gestures
}

\author{
güero/a \\ adjective, noun \\ ['gwero/a] \\ Méx. Dicho de una persona: Que tiene los cabellos rubios. \\ [1. Mex. Said about a person: that has blond hair.] \\ Diccionario de la lengua española.
}


Only when the strutting takes place over corpses do we get the social gest of Fascism. This means that the artist has to adopt a definite attitude towards the fact of pomp; [they] cannot let it just speak only for itself, simply expressing it as the fact dictates.

Bertold Brecht (2014: 169).

How do you make a body accountable for its language, its positioning?

Why not make a body accountable for its language?

Claudia Rankine (2014).

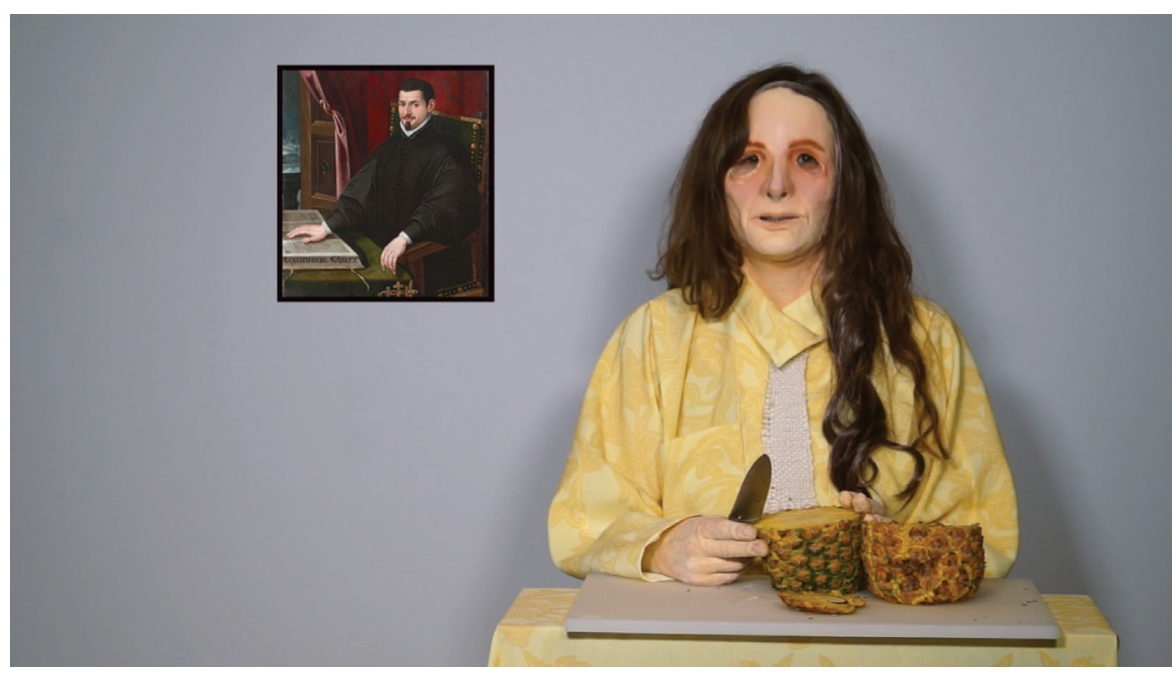

Figure 3.

In the common use of Mexican Spanish the word güero/a refers to what whiteyness stands for: street or market vendors call (loudly and wheedlingly!) a potential costumer "güero/a" or "güerito/a" even when the person is not light-skinned as (what comes now as no surprise!) güero/a is associated with higher social class, power and money. At the market, one can buy mugs (or T-shirts) with 
the slogan En el tianguis todos somos güeritos [At the market we're all güeritos].

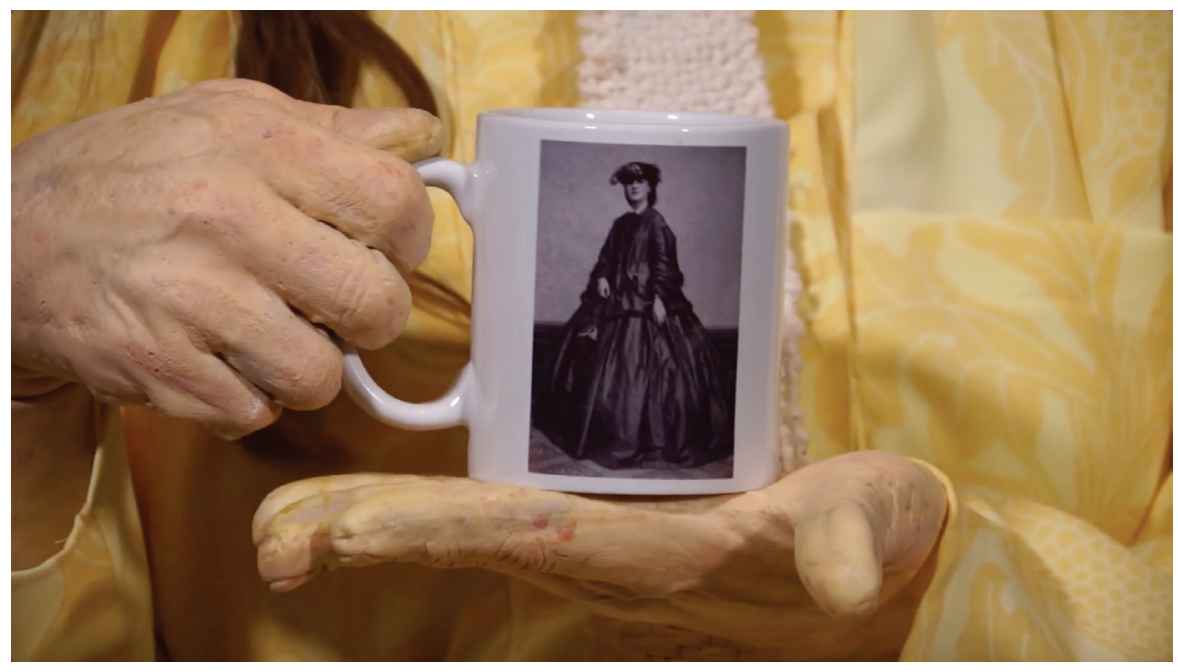

Figure 4.

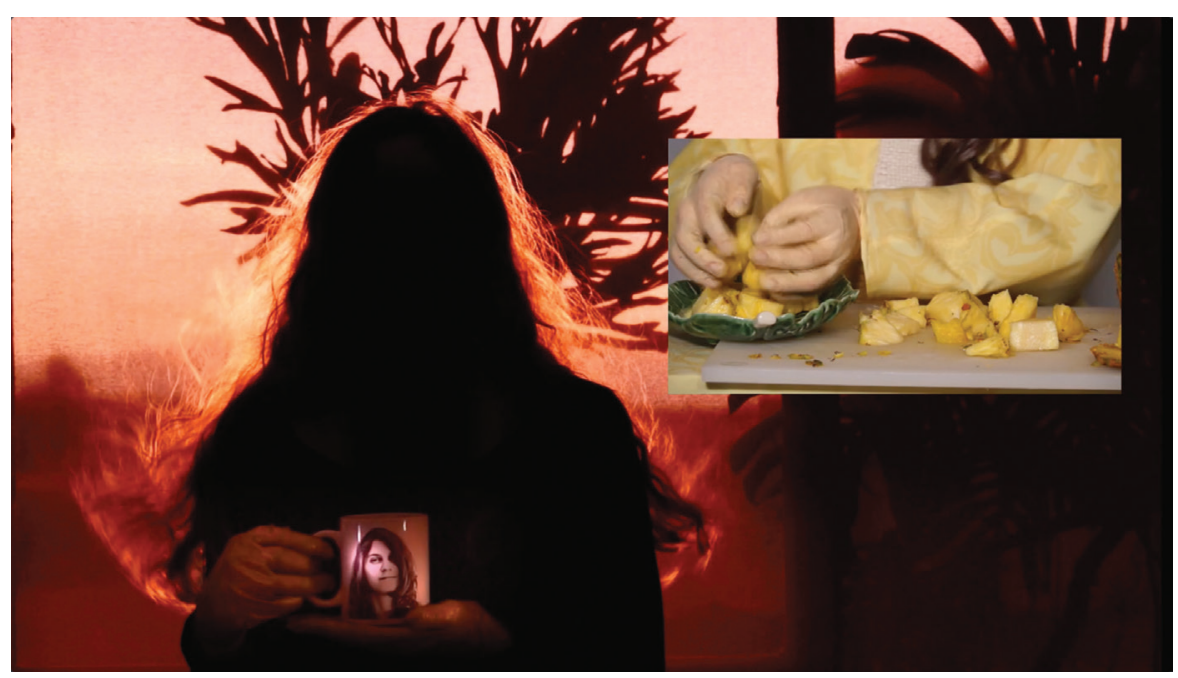

Figure 5. 
In the film, La güera uses mugs to introduce and, if possible, show portraits of the key characters: Maximilian of Habsburg, Charlotte of Belgium, Jean-Friedrich Waldeck, Teobert Maler and Anton "Toni" Mayr-all of them güerxs and, somehow, related to the contemporary Republic of Austria. A mysterious know-it-all figure from the early years of the twenty-third century, who disrupts La güera's narrations time and again, does the same when introducing the maker of the film from 2018: Nina Hoechtl-a güera too, and an Austrian citizen who holds a permanent resident card in Mexico. (Yes, me!)

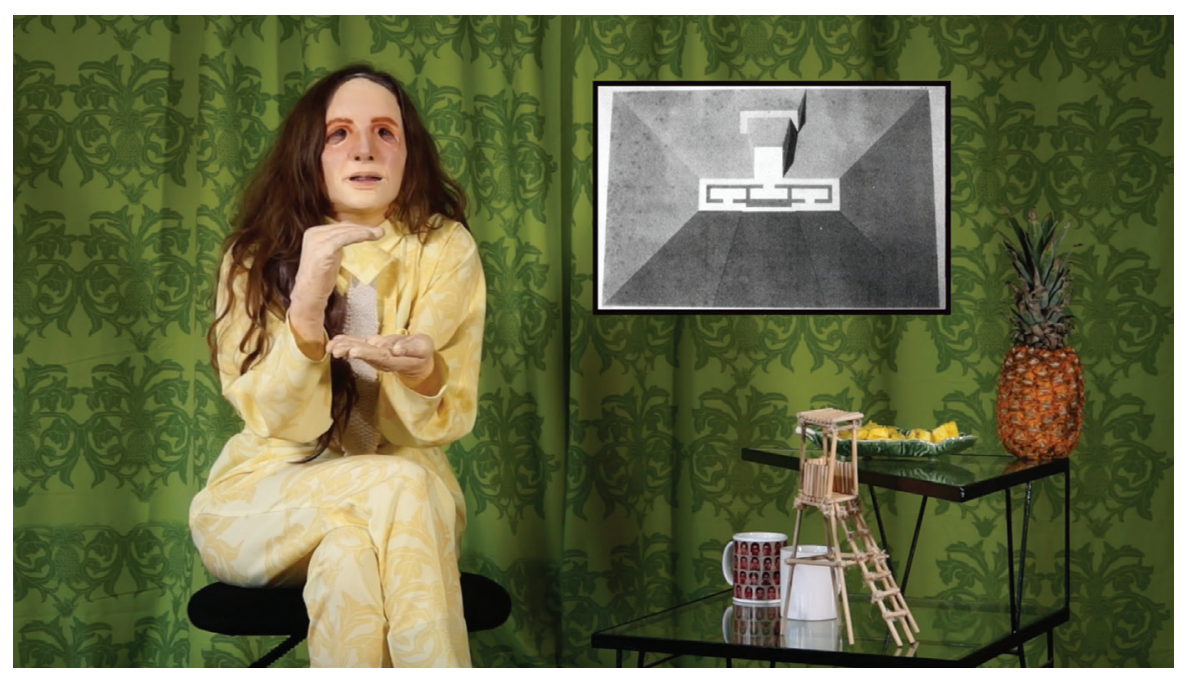

Figure 6.

Alongside the latex face and hand masks it is through the performance of güero gestures that the host, La güera, takes on her whitey identity. "[G]estures have to be considered as events, singular performances", according to Carrie Noland (2008: xxiv). These events "draw ... on culture-specific (as well as gender-, race-, sexuality-, and class specific) conventional vocabularies" (Noland 2008: xxiv), while the repetition remains central to the gestural formation. Through repetitions güero gestures become recognizable. They 
show how much one has compromised and mastered to perform the abstract-universal identity of blanquitud that La güera undoubtedly displays.

Let's take a look at the most recurrent güero gesture in the film, the self-feeding gesture: La güera satisfies herself time and again by grabbing the-for her-always available, sweet hybrid MD2 pineapple, bringing it to her mouth and eating it. Like the majority of the world with an ever-growing greed for an all seasons long access to pineapples, since the early 2000s she has neglected the other six major types of pineapple, the ones that are less sweet and durable, smaller, more tender and cannot withstand commercial handling as easily. "By ignoring the fruit's genetic base in the wild, we risk losing the genes they contain and undermining the future of the fruit" (Pearce 2008).

If "the politics of 'what gets eaten' or consumed is bound up with histories of imperialism" (Ahmed 2004: 83) and the abstract-universal identity of blanquitud is operating as hierarchically and economically superior and as such it is still deemed the desired identity (with an unfettered access to any fruit, vegetable, plant, creature, soil, practice and knowledge production at anytime, anywhere serving the rapacious appetite for consumption, study, accumulation, appropriation, (genetic) manipulation, commodification, profit), there is an urgent sociopolitical need to comprehend why it is so-to comprehend its power through the lens of colonial imperial histories.

It is the complex interplay between identity as immaterial-a concept-and identity as material-fleshy, and, in the case of the film, latex-that the güero gestures express, (re)enact and (re)cite. In the film, each (hi)story is the future of the other, or perhaps each (hi)story is the premonition of the other while being its past. Only the constant process of debunking how, when, where and 
why blanquitud works and is performed, and how it informs and is informed by images, might give some common ground, some understanding, from which some agency can emerge. ${ }^{3}$

\section{Haunted Assemblages Disrupted}

I [use] the term haunting to describe those singular yet repetitive instances when home becomes unfamiliar, when your bearings on the world lose direction, when the over-and-donewith comes alive, when what's been in your blind spot comes into view.

Avery F. Gordon (2008: xvi).

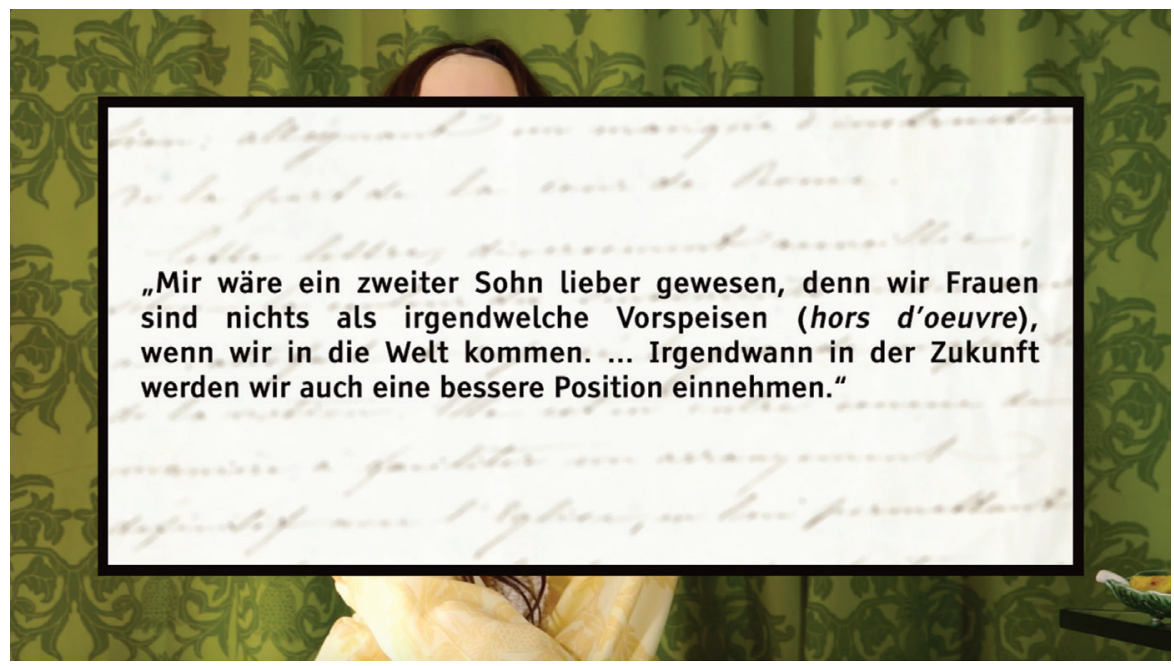

Figure 7.

3 In Modernidad y blanquitud (Modernity and Blanquitud), Echeverría (2010) shows how images by Hans Holbein, Grant Wood and Adolf Ziegler, among others, feed into blanquitud. 


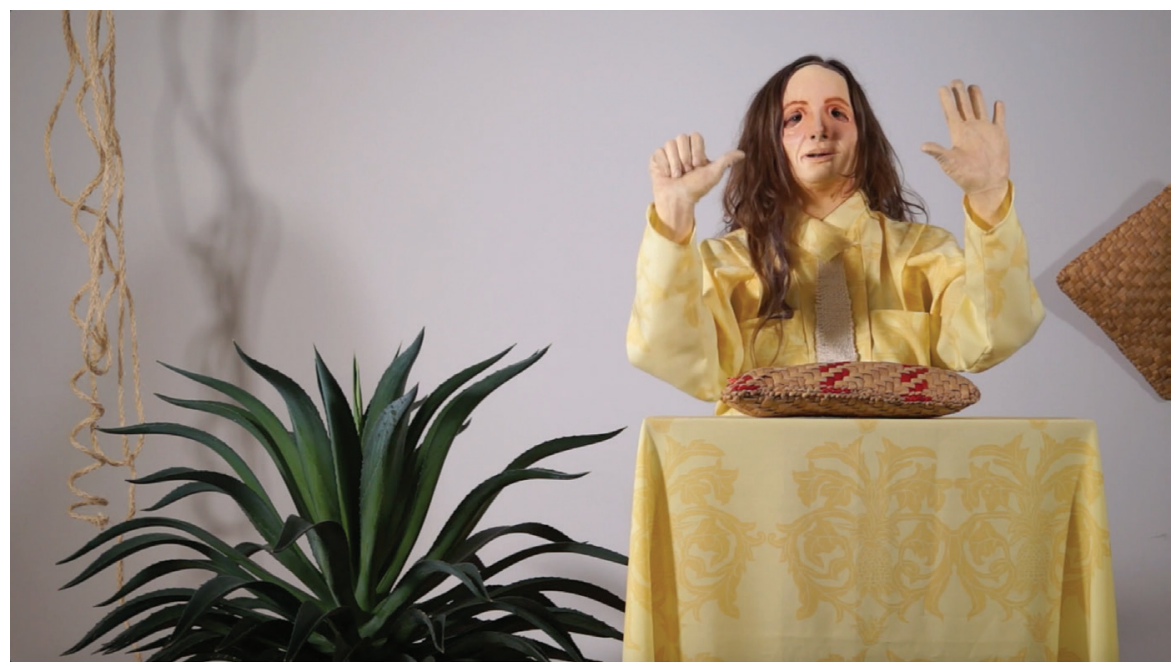

Figure 8.

The film assembles a repertoire of archival images, texts and acts left behind by colonial imperial practices. They all relate to the construction of the delirio güero that entangles with race, ethnicity, gender, class, entitlement, nationality or peoplehood, and violence in Mexico. The themes of the repertoire are haunted. They are repetitive to a degree that would be bromidic and ridiculous were these tropes not so devastating in their effects. In the film, La güera dives into and moves through some of these effects in assemblages of objects and props specifically made for the film (such as the mugs), archival images that are framed within the frame as a (form of) quotation (mark), the performative form of güero gestures, and narratives in two versions: in German and in Spanish spoken in foreign accents by two different voice-overs: Mariel Rodríguez, a visual artist from Mexico currently living and working in Vienna, and myself, respectively. (And, for the English-speaking audience, available with English subtitles.) Let's pause for a moment. 


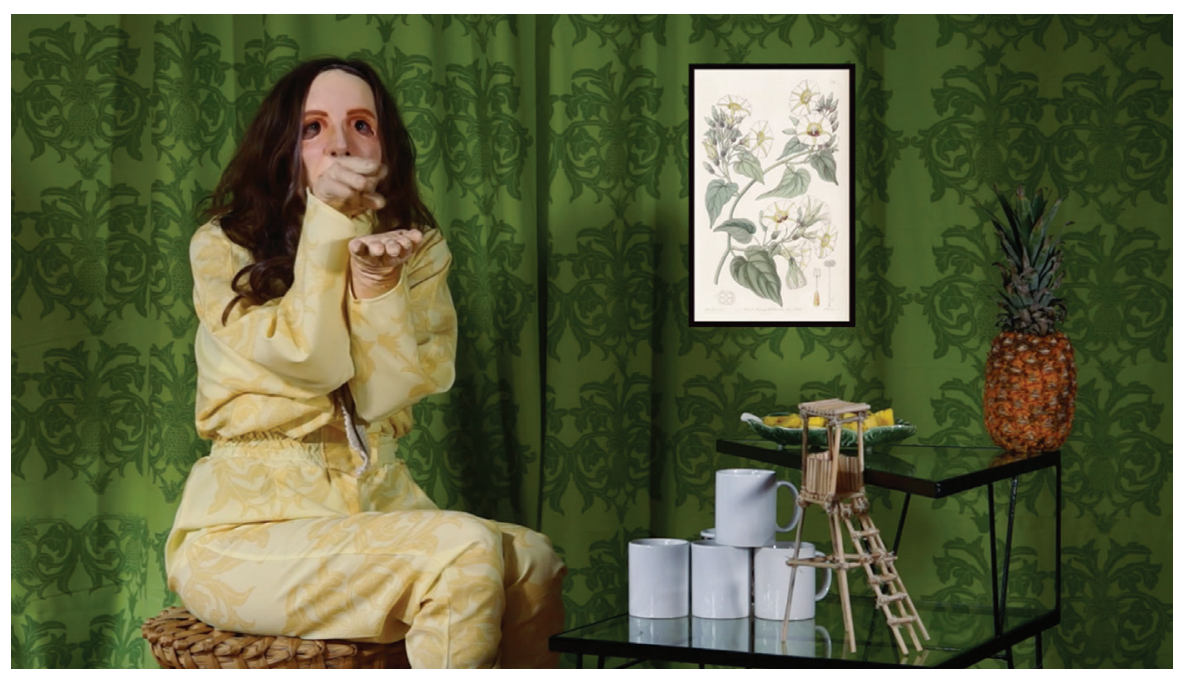

Figure 9.

Let's pause in a scene when the mysterious know-it-all figure disrupts La güera's narrations of effects that she (so readily!) casts off by telling what substances might have been consumed-ololiuqui seeds - that led to such doings - the making of the portrait of Charlotte and Maximilian with the Lady of Guadalupe. This carte-de-visite is haunted. It is haunted by what Ariella Azoulay (2018) proposes to unlearn: the origins of photography. Azoulay invites us to imagine that these origins go back to 1492, the year when the Spanish Empire began its conquest and colonization of the "New World". It is sometime in the early nineteenth century that common theories and histories locate photography's moment of emergence around technological development and men inventors. In a world that had already been colonized, enabling the reproduction of imperial rights and violence, Azoulay (2018) argues, photography was institutionalized as a visual and communicative practice. It articulates in images what Azoulay (2018) describes as "the right to destroy", to accumulate, to appropriate, to differentiate, to record what had been destroyed or appropriated, to study, rescue, salvage/plunder and exhibit it. 


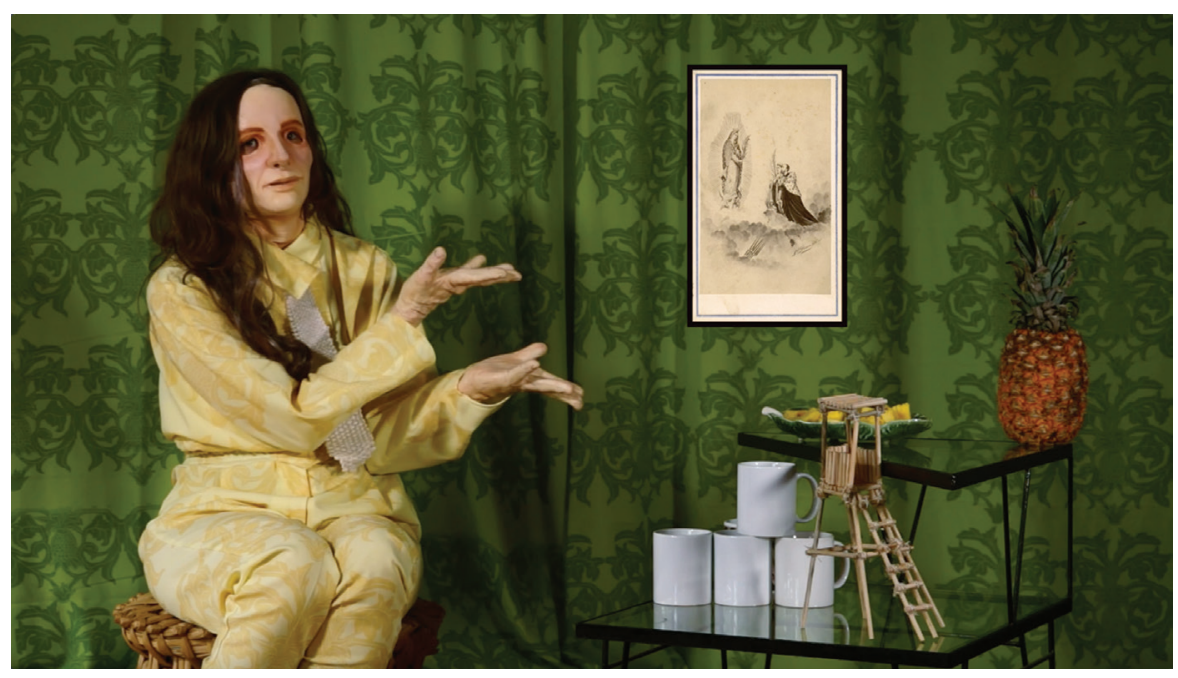

Figure 10.

In the film, the carte-de-visite titled Our Lady of Guadalupe appearing to the Emperor and Empress in the Clouds above the Cerro de las Campanas (1860s) shows how the right to destroy, appropriate and differentiate by the Second Mexican Empire of Maximilian and Charlotte was masked by the appropriation and exhibition of the Lady of Guadalupe. In 1531, this right to destroy, appropriate and differentiate had already been applied when one of Mexica ${ }^{4}$ sacred sites, the Tepeyac hill north of Mexico City, was

4 I use the term "Mexica" instead of "Aztec". The Nahuatl-speaking group, who settled on an islet in Lake Texcoco in 1325, founding the cities of Tenochtitlan and Tlatelolco-known today as Mexico City-referred to themselves as the "Mexihcah". In addition to the Mexihcah, however, there were quite a few other groups that spoke roughly the same language (Nahuatl) living near those highland lakes: the Xochimilcah, the Tlaxcaltecah, the Tepanecah, the Tetzcohcah, the Tlacopanecah etc. Those last two groups joined with the Mexihcah to form the Ēxcān Tlahtōlōyān (the Triple Alliance) - known today as the Aztec Empire. Aztec is therefore a misnomer if one refers to the culture and inhabitants of Tenochtitlan and Tlatelolco. For more on the use of "Mexica" and 
appropriated for the appearance of the Lady of Guadalupe to Juan Diego. Before conquest this very same site had been used by Mexicas to worship Tonantzin. In Mexica culture and mythology, Tonantzin is a term used to designate different female deities (not just one!), such as Coatlicue, Cihuacóatl and Teteoinan. By the beginning of the seventeenth century, this site had been further appropriated and differentiated by building a church. By the middle of the nineteenth century the image of the Lady of Guadalupe purposefully ended up in Maximilian and Charlotte's carte-de-visite. Without a doubt, this carte-de-visite is but one example of being part of the imperial world, which Azoulay (2018) advocates to explore: "unlearn the expertise and knowledge that call upon us to account for photography as having its own origins, histories, practices, or futures, and to explore it as part of the imperial world in which we, as scholars, photographers ... curators [or film-makers] operate".

Haunted materials concern the disruption of the familiar affordances of images (for example, how they enable and constrain "taken-for-granted" modes of their origin and making meaning). Haunted assemblages disrupted are concerned with how practices with images as part of the imperial world can be shifted and the habitual sense we make of them can be disrupted such that the configuration of materiality, narratives, space, subjects and the past as it was produced show up and are enabled: the challenge of how to work with images that wear the invisible mask of history yet largely denied historicity to their subjects keeps necessarily resonating in (between) all of it.

\footnotetext{
“Aztec”, see Miguel León-Portilla, "Los Aztecas. Disquisiciones sobre un Gentilicio," [The Aztecs. Disquisitions on a Demonym]. Estudios de Cultura Náhuatl 31, 2000: 307-313.
} 
NINA HOECHTL is an independent artist, researcher, writer, curator, and educator. She can be reached at nina.hoechtl@gmail.com

\section{References}

Sara Ahmed. 2004. The Cultural Politics of Emotion. New York: Routledge.

APA. 2013. Fifth Edition of the Diagnostic and Statistical Manual of Mental Disorders (DSM-5). Washington, DC: American Psychiatric Association.

Azoulay, Ariella. 2018. "Unlearning the Origins of Photography". Still Searching..., 6 September. https://www.fotomuseum.ch/en/explore/still-searching/articles/155239_unlearning_the_origins_of_ photography.

Brecht, Bertolt. 2014. Brecht on Theatre: The Development of an Aesthetic. Tom Kuhn, Steve Giles and Marc Silberman (eds). London: Bloomsbury.

Cohen, Stanley. 2001. States of Denial: Knowing about Atrocities and Suffering. Malden, MA: Polity Press.

Diccionario de la lengua española [Spanish Language Dictionary], "güero". https://dle.rae.es/?id=JoL4KZT|JoMva2U.

Echeverría, Bolívar. 2009. “'Blanquitud'. Considerations on Racism as a Specifically Modern Phenomenon". Paper presented at the International Conference ON MODERNITY, University of Vienna, 11-14 December.

Echeverría, Bolívar. 2010. Modernidad y blanquitud [Modernity and Blanquitud]. Mexico City: Ediciones Era.

Echeverría, Bolívar. 2018. Racismo y Blanquitud [Racism and Blanquitud]. Mexico City: Zineditorial.

Fanon, Frantz. 1986. Black Skin, White Masks. London: Pluto Press.

Fassbinder, Rainer Werner, Whity. 1971; San Francisco, CA: Fantoma, 2003. DVD. 
Gorden, Avery F. 2008. Ghostly Matters. Haunting and the Sociological Imagination. Minneapolis, MN, and London: University of Minnesota Press.

León-Portilla, Miguel. 2000. “Los Aztecas. Disquisiciones sobre un Gentilicio" [The Aztecs.

Disquisitions on a Demonym]. Estudios de Cultura Náhuatl 31: 307-313.

http://www.ejournal.unam.mx/ecn/ecnahuat|31/ECN03113.pdf.

Layne, Prisciall D. 2012. "Lessons in Liberation: Fassbinder's Whity at the Crossroads of Hollywood Melodrama and Blaxploitation". Companion to German Cinema. Terri Ginsberg and Andrea Mensch (eds). Malden, MA: Wiley Blackwell Press.

Marcos, Subcomandante. 1995. “Interview: Subcomandante Marcos". Interview by Medea Benjamin. First World, Ha Ha Ha! The Zapatista Challege, Elaine Katzenberger (ed.). San Francisco: City Lights.

Noland, Carrie. 2008. "Introduction" in Carrie Noland and Sally Ann Ness, Migrations of Gesture. Minneapolis, MN: University of Minnesota Press.

Pearce, Fred. "The Sterile Banana”. Conservation, 26 September. https://www.conservationmagazine.org/2008/09/the-sterile-banana.

Rankine, Claudia. 2014. "Claudia Rankine on Blackness as the Second Person". Guernica, 17 November. https://www.guernicamag.com/ blackness-as-the-second-person.

Figures 1-10: Nina Hoecht1. 2019. DELIRIO GÜERO WHITE DELUSION 1825, 2018, 2211 and back. Video. Still: Rafael Ortega.

If you would like to watch the video do not hesitate to drop a line: nina.hoechtl@gmail.com 